\title{
正誤表 (Errata)
}

日本水産学会誌第 83 巻 6 号（November 2017） 1025 頁の「シンポジウム記録 水産資源管理の国際協力 $\mathbb{I I}-1$. 日 本型共同管理アプローチ」(牧野) に誤りがありましたので，訂正いたします。

（図 1 の見出し）

誤 :

図 1 水産システムの概念図（水産機構 2017）
正 :

図 1 水産システムの概念図（水産機構 $\mathrm{http://sh-u-}$ n.fra.go.jp/から引用) 